\title{
Investigations of operational driving loads of bucket chains and manoeuvre hoisting winches on multi-bucket dredgers
}

\author{
Damian Bocheński, Ph. D. \\ Gdansk University of Technology
}

\section{ABSTRACT}

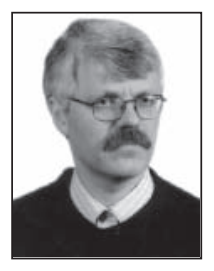

The paper concerns problems of preliminary designing of bucket dredgers' power plants. This paper presents results of investigations of six bucket dredgers in service. The operational investigations consisted in measuring the parameters which characterize working conditions of two main receivers of mechanical energy: bucket chains and swing winches. In the paper characteristics of disposition of loading of bucket chains and swing winches are presented. They covered average value, standard deviation and coefficient of variance of loading disposition mutability. Examples of load distributions of chains' and group of swing winches on chosen dredgers during some period of time were given. Conclusions in view to average values of main receivers of mechanical energy and coefficients of variance of loadings spred were formulated. Results of investigations of dependence of average loadings of main receivers on their nominal power were presented. The results of work will be used in creation of random models describing real conditions of operation of power plant elements of dredgers.

Keywords: Bucket ladder dredgers, main receivers of mechanical energy, ship power plants, bucket chain, swing winches

\section{INTRODUCTION}

The main mechanical energy consumers on dredgers, regardless of their type, are intended for realizing the following technological processes [2]:

$\Rightarrow$ loosening, dredging and transporting the soil

$\Rightarrow$ positioning, manoeuvring and possible propelling the dredger.

Bucket chains and set of manoeuvre hoisting winches are the main consumers in question on multi-bucket dredgers in their basic design solution [7]. Knowledge of operational loads of main consumers is crucial problem in preliminary designing the dredger power plant. This paper presents results of service investigations dealing with driving loads of bucket chains and set of manoeuvre hoisting winches on multi-bucket dredgers. The investigations constituted a part of a greater research project on energy consumption of technological processes on dredgers of three basic types, performed in the years $2000 \div 2003$ and $2005 \div 2006[5,8]$. As to the multi-bucket dredgers, five such dredgers were subjected to the investigations and their results were supplemented with results of the tests carried out on the dredger Ivan Bachvalov by a measuring team of RCP$\mathrm{KB}$ design office in Rostow upon Don [10].

The main technical data of the dredgers, concerning the parameters of bucket chains and maoeuvre hoisting winches, are presented in Tab. 1.

On all the investigated dredgers the bucket chains and manoeuvre hoisting winches were driven by diesel-electric power systems. The measurements were preformed with the use of specially designed measuring systems consisted of electronic digital multimeters co-operating with computer $[4,5]$. The multimeters were used to measure and record versus time electric current (indirect measurement by shunt -voltage measuring) and voltage (direct measurement). This way value of the power consumed by electric motors driving a given consumer, was determined. By making use of the results and knowing efficiency characteristics of power transmission systems, instantantaneous power values at drive coupling of a given main consumer, were determined. Operational loads of bucket chain are subjected to great and frequent changes, that results from character of consumer's working mode. The changeability of loads is associated mainly with cutting-in successive buckets to the soil (every $3 \div 4 \mathrm{sec}$ on average). How large is the changeability can be illustrated by the mean value of the coefficient $\mathrm{N}_{\mathrm{LC}}^{\max } / \mathrm{N}_{\mathrm{LC}}^{\min }$ equal to 4.5 calculated for several loadings of a hopper barge during preliminary service measurements [5]. For the reason of the highly changeable character of bucket chain loads it was assumed that the measurements of the loads of the bucket chains and set of manoeuvre hoisting winches, will be performed every second [5].

In order to determine the driving load characteristics of bucket chains and manoeuvre hoisting winches it is necessary to know changes of the loads occurring for a long time. Large number of instantaneous values of loads makes it possible to properly perform their statistical estimation. The mean duration time of dredging work carried out by multi-bucket dredgers at sea amounts to about $2500 \mathrm{~h} /$ year [5]. Because of limited possibility of carrying out the measurements for such a long period on each of the investigated dredgers it was planned to 
perform the service investigations for at least $5 \%$ of the working period of each of the investigated dredger, i.e. for about $125 \mathrm{~h}$. As a rule the service investigations were carried out in $24 \mathrm{~h}$ cycle. Overall, the measurements were carried out for $732 \mathrm{~h}$ [8]. Number of samples for every investigated dredger was greater than 300000 and significantly exceeded the minimum number of samples [9].

Tab. 1. Main technical data of the multi-bucket dredgers subjected to the investigations in service

\begin{tabular}{|c|c|c|c|c|c|c|}
\hline \multirow{3}{*}{$\begin{array}{c}\text { Dredger's } \\
\text { name }\end{array}$} & \multicolumn{2}{|c|}{$\begin{array}{l}\text { Bucket- } \\
\text { chain drive } \\
\text { parameters }\end{array}$} & \multicolumn{3}{|c|}{$\begin{array}{c}\text { Drive } \\
\text { parameters of } \\
\text { set of manoeuvre } \\
\text { hoisting winches }\end{array}$} & \multirow{2}{*}{$\mathrm{Q}_{\mathrm{PW}}$} \\
\hline & $\mathrm{N}_{\mathrm{LC}}^{\text {nom }}$ & $\mathrm{N}_{\mathrm{LC}}$ & $\mathrm{T}_{\mathrm{wM}}$ & $\mathrm{v}_{\mathrm{WM}}$ & 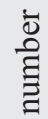 & \\
\hline & $\mathrm{kW}$ & $\begin{array}{c}\text { n. bckts/ } \\
\text { min }\end{array}$ & $\mathrm{kN}$ & $\mathrm{m} / \mathrm{min}$ & - & $\mathrm{m}^{3} / \mathrm{h}$ \\
\hline Malı̇ II & 88 & 24 & 57 & 10 & 4 & 250 \\
\hline Rozgwiazda & 300 & 19 & 90 & 12 & 4 & 640 \\
\hline Inż. T. Wenda & 310 & 19 & 90 & 12 & 4 & 640 \\
\hline Usedom & 420 & 25 & $\begin{array}{l}155 \\
81.5\end{array}$ & $\begin{array}{l}17.5 \\
17.5\end{array}$ & $\begin{array}{l}2 \\
2\end{array}$ & 840 \\
\hline Kategats & 400 & 25 & $\begin{array}{r}155 \\
81.5\end{array}$ & $\begin{array}{l}17.5 \\
17.5\end{array}$ & $\begin{array}{l}2 \\
2\end{array}$ & 800 \\
\hline $\begin{array}{c}\text { Ivan } \\
\text { Bachvalov }\end{array}$ & 400 & 25 & $\begin{array}{l}155 \\
81.5\end{array}$ & $\begin{array}{l}17.5 \\
17.5\end{array}$ & $\begin{array}{l}2 \\
2\end{array}$ & 800 \\
\hline
\end{tabular}

where:

$\mathrm{N}_{\mathrm{LC}}^{\text {nom }}$ - bucket chain nominal power

$\mathrm{N}_{\text {LC }}^{\text {LC }}$ - bucket chain speed

$\mathrm{T}_{\mathrm{WM}}^{\mathrm{LC}} \quad$ - hoisting winch pull

$\mathrm{V}_{\mathrm{WM}}$ - hauling speed of manoeuvre hoisting winch

$\mathrm{Q}_{\mathrm{PW}} \quad$ - design dredging rate of a dredger.
The performed investigations made it possible to determine the driving load distribution characteristics for bucket chains and set of manoeuvre hoisting winches during soil dredging operations, namely these of:

$\mathrm{N}_{\mathrm{LC}}^{\mathrm{sr}} / \mathrm{N}_{\mathrm{WM}}^{\mathrm{sr}}$ - mean load of bucket chain and manoeuvre hoisting winches, respectively

$\sigma_{\mathrm{LC}}, \sigma_{\mathrm{WM}}-$ standard deviations of load distributions of bucket chain and manoeuvre hoisting winches,

$v_{\mathrm{LC}}=\frac{\sigma_{\mathrm{LC}}}{\mathrm{N}_{\mathrm{LC}}^{\mathrm{sr}}}-\begin{aligned} & \text { respectively } \\ & \text { coefficient of variation of bucket chain load }\end{aligned}$ distribution

$v_{\mathrm{WM}}=\frac{\sigma_{\mathrm{WM}}}{\mathrm{N}_{\mathrm{WM}}^{\mathrm{sr}}}-$ coefficient of variation of load distribution of $\mathrm{N}_{\mathrm{WM}}^{\mathrm{sr}}$ manoeuvre hoisting winches

$\lambda_{\mathrm{LC}}^{\mathrm{cz}}, \lambda_{\mathrm{WM}}^{\mathrm{cz}}$ - coefficients which determine participation of working period of bucket chain and manoeuvre hoisting winches during dredging, respectively.

\section{OPERATIONAL LOADS OF BUCKET CHAINS}

The investigations of load distribution characteristics of bucket chains were performed with taking into account kind of dredged soil. During the performed operational investigations the following kinds of soil were dredged:

- medium soils of the in- the- site density of $1.7 \div 1.95 \mathrm{t} / \mathrm{m}^{3}$, which can be additionally divided into:

- non-cohesive soils, fine- and medium- grain, mediumcompacted sandy soils

- cohesive soils, medium sandy and plastic silts

- light soils of the in- the- site density of $1.4 \div 1.6 \mathrm{t} / \mathrm{m}^{3}$

- warps with loose sands or quick clays.

The operational measurement results for bucket chains supplemented with those performed on the dredger Ivan Bachvalov [10] are shown in Tab. 2, and in Fig. 1 - the example histograms of the operational loads for selected dredgers. The loads were grouped into 10 left-sidedly-opened intervals of quantization which covered the range $\left(\mathrm{N}_{\mathrm{LC}}^{\min }-\mathrm{N}_{\mathrm{LC}}^{\max }\right)$; the values of $\mathrm{N}_{\mathrm{LC}}^{\min }$ and $\mathrm{N}_{\mathrm{LC}}^{\max }$ were taken into account as integers most close to real measurement results.

Tab. 2. Characteristics of bucket chain load distributions for multi-bucket dredgers

\begin{tabular}{|c|c|c|c|c|c|c|c|c|}
\hline \multirow{2}{*}{$\begin{array}{l}\text { Kind of } \\
\text { soil }\end{array}$} & \multirow{2}{*}{$\begin{array}{l}\text { Name of } \\
\text { dredger }\end{array}$} & $\mathrm{N}_{\mathrm{LC}}^{\mathrm{nom}}$ & $\mathrm{N}_{\mathrm{LC}}^{\mathrm{sr}}$ & $\overline{\mathrm{N}_{\mathrm{LC}}^{\mathrm{sr}}}$ & $\sigma_{\mathrm{LC}}$ & $v_{\mathrm{LC}}$ & $\lambda_{\mathrm{LC}}^{\mathrm{cz}}$ & \multirow{2}{*}{ Source of information } \\
\hline & & $\mathrm{kW}$ & $\mathrm{kW}$ & - & $\mathrm{kW}$ & - & - & \\
\hline \multirow{7}{*}{ Medium } & Malł̇ II & 88 & $\begin{array}{l}28.16^{1)} \\
28.92^{2)}\end{array}$ & $\begin{array}{c}0.32 \\
0.329\end{array}$ & $\begin{array}{c}9.67 \\
10.76\end{array}$ & $\begin{array}{l}0.343 \\
0.372\end{array}$ & $\begin{array}{l}0.97 \\
0.94\end{array}$ & the author's investigations \\
\hline & Inż. T. Wenda & 310 & $\begin{array}{c}105.19^{1)} \\
99.32^{2)}\end{array}$ & $\begin{array}{c}0.339 \\
0.32\end{array}$ & $\begin{array}{l}34.74 \\
42.95\end{array}$ & $\begin{array}{l}0.331 \\
0.432\end{array}$ & $\begin{array}{l}0.98 \\
0.95\end{array}$ & ditto \\
\hline & Rozgwiazda & 300 & $\begin{array}{l}99.78^{1)} \\
92.37^{2)}\end{array}$ & $\begin{array}{l}0.333 \\
0.308 \\
\end{array}$ & $\begin{array}{l}30.96 \\
33.79 \\
\end{array}$ & $\begin{array}{c}0.31 \\
0.366 \\
\end{array}$ & $\begin{array}{l}0.98 \\
0.97\end{array}$ & ditto \\
\hline & Usedom & 420 & $183.44^{1)}$ & 0.437 & 41.62 & 0.227 & 0.99 & ditto \\
\hline & Kategats & 400 & $195.68^{1)}$ & 0.489 & 42.35 & 0.216 & 0.98 & ditto \\
\hline & Ivan Bachalov & 400 & $186.64^{1)}$ & 0.467 & 46.84 & 0.251 & & {$[10]$} \\
\hline & Mean values & & & $0.398^{1)}$ & & $0.281^{1)}$ & 0.97 & \\
\hline \multirow{7}{*}{ Light } & Maṫ் II & 88 & 21.22 & 0.241 & 4.03 & 0.189 & 0.96 & the author's investigations \\
\hline & Inż. T. Wenda & 310 & 92.73 & 0.299 & 14.28 & 0.154 & 0.98 & ditto \\
\hline & Rozgwiazda & 300 & 90.98 & 0.303 & 16.91 & 0.186 & 0.97 & ditto \\
\hline & Usedom & 420 & 158.93 & 0.378 & 29.93 & 0.188 & 0.99 & ditto \\
\hline & Kategats & 400 & 172.86 & 0.432 & 21.48 & 0.124 & 0.99 & ditto \\
\hline & Ivan Bachalov & 400 & 165.91 & 0.415 & 28.67 & 0.173 & & {$[10]$} \\
\hline & Mean values & & & 0.345 & & 0.169 & 0.98 & \\
\hline
\end{tabular}

${ }^{1)}-$ medium sands, ${ }^{2}$ - medium silts 
a)

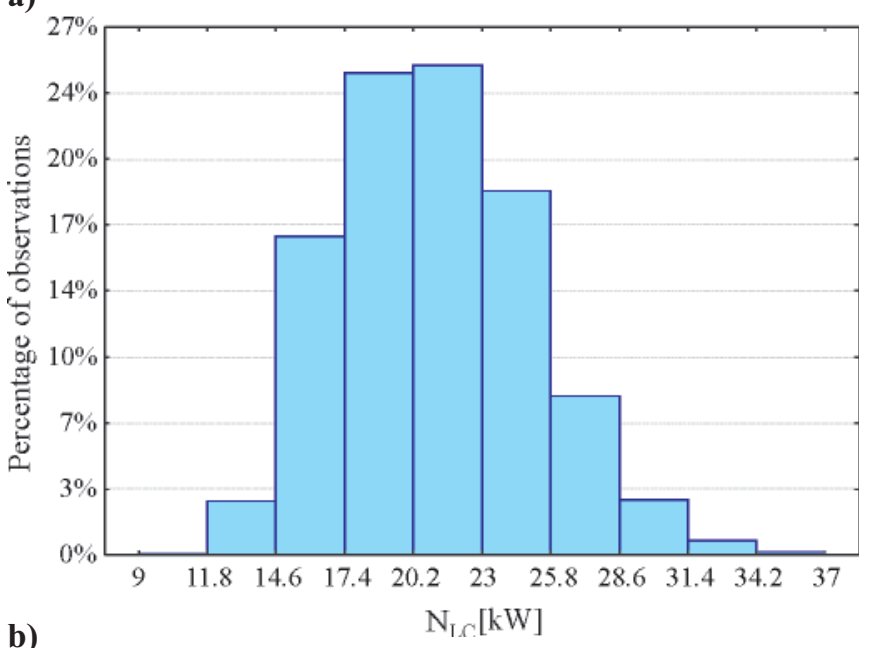

b)

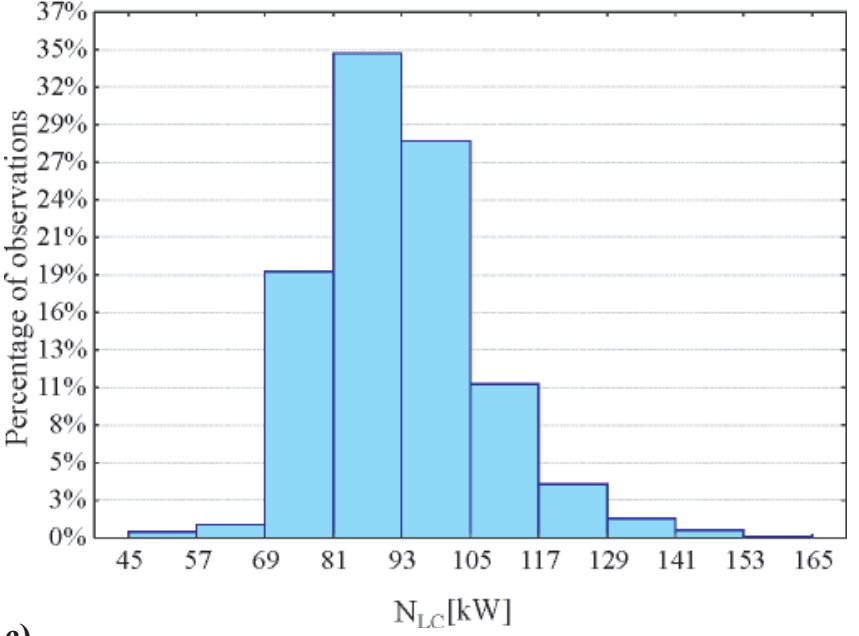

c)

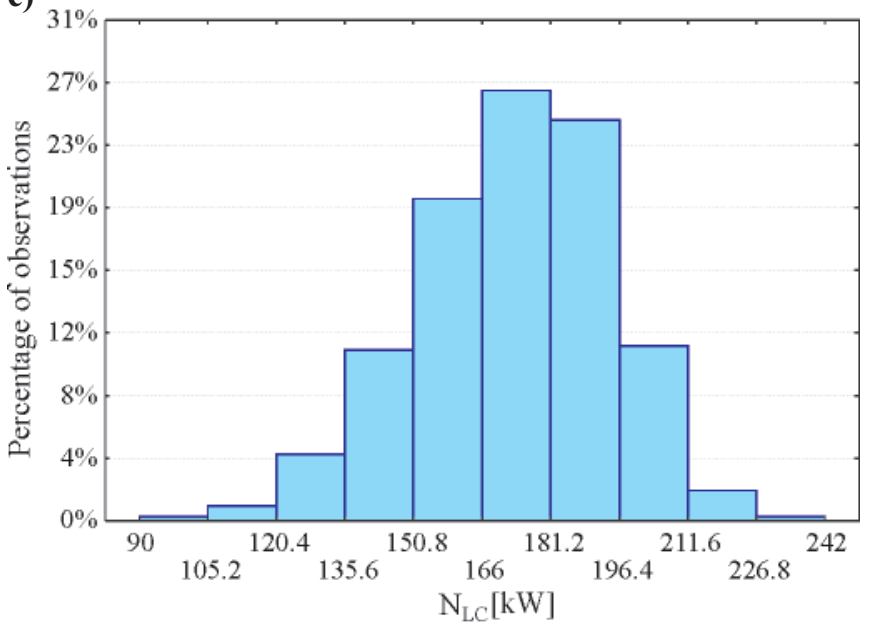

Medium soils
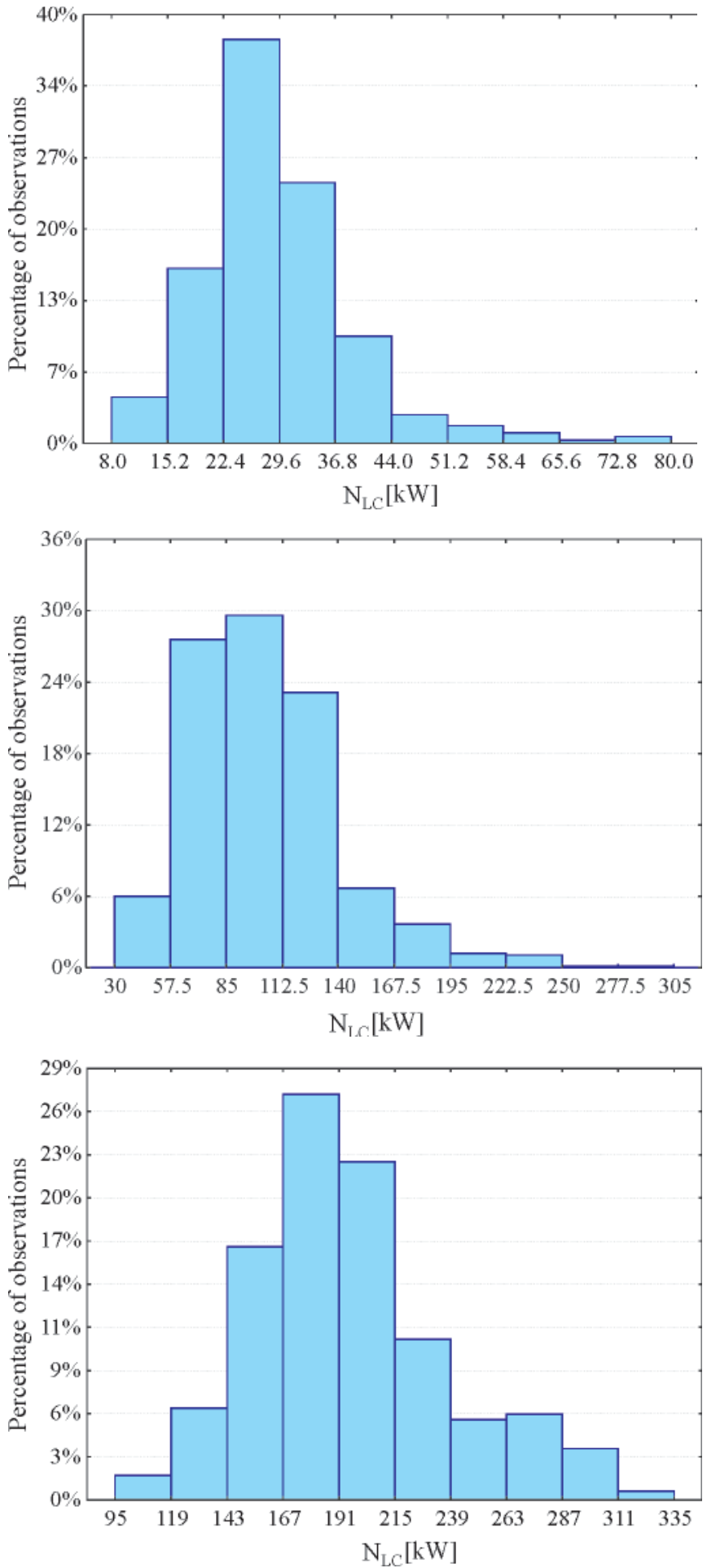

Fig. 1. Histograms of operational bucket chain loads on the multi-bucket dredgers: a) Malż II, b) Inż. T. Wenda, c) Kategats

The measurement results confirm the influence of kind of soil on operational characteristics of bucket chains. Distinct difference can be observed in values of the bucket chain load distribution parameters of the same dredger working in light and medium soils. The values of the mean relative bucket chain loads $\mathrm{N}_{\mathrm{LC}}^{\mathrm{sr}}$ for medium soils are greater by about $15-20 \%$ than those for light soils of the same dredger. Differences in values of the variation coefficients of the bucket chain load distribution, $v_{\text {LC }}$, are significant: for medium soils they are contained in the interval of $(0.216 \div 0.432)$, and for light soils - in the interval of $(0.124 \div 0.189)$.

The differences in the bucket chain load distribution parameters during dredging the medium soils - regardless non-cohesive and cohesive - are practically neglectable. The differences in the mean relative bucket chain load values are rather small: in two cases - a little greater during dredging the non-cohesive soils, and in one case - during dredging the cohesive soils. The differences concerning values of variation coefficient of bucket chain load distribution seem a little more significant. In all the three cases the values were greater for dredging the cohesive soil. They amounted respectively to $(0.366 \div 0.432)$ in the case of dredging the cohesive soils and $(0.31 \div 0.343)$ - in the case of dredging the non-cohesive ones.

Analyzing the results of Tab. 2 one can clearly observe the differences in values of $\overline{\mathrm{N}_{\mathrm{LC}}^{\mathrm{sr}}}, v_{\mathrm{LC}}$ - especially at dredging medium soils - for the three first dredgers as compared with 
three next ones. This situation can be explained by kind of work realized by a given dredger. Generally two types of dredging can be distinguished: investment work and maintenance work. The investment work, as compared with maintenance work, is characterized by a higher effectiveness and in consequence - higher bucket chain loads. Medium and small size dredgers are generally intended for maintenance work. Large dredgers are much more engaged in investment work $[5,6]$. Among the investigated dredgers only one, the smallest dredger Matz II, was characterized by almost $80 \%$ participation in maintenance work; the larger ones: Rozgwiazda and Inz. T. Wenda were engaged by about $50-60 \%$ in investment work. The three largest ones performed only investment operations and for this reason they were characterized by the largest values of the mean relative loads of bucket chains. The carrying-out of investment operations probably results also in somewhat smaller values of variation coefficient of bucket chain load distribution. Worth stressing that the above mentioned percentage values of duration time of carrying-out investment and maintenance work are typical for the multi- bucket dredgers of the investigated size $[5,6]$.

Values of the coefficient $\lambda_{\mathrm{LC}}^{\mathrm{cz}}$ are contained in the interval of $0.94 \div 0.99$ and they do not depend on kind of dregded soil.

\section{OPERATIONAL LOADS OF SET OF MANOEUVRE HOISTING WINCHES}

The investigations of operational loads of manouvre hoisting winches concerned the set of four winches. In manoeuvres also two other winches took part, however they were not considered to be main consumers because of their short-lasting period of work [6].

The results of operational measurements of the set of manoeuvre hoisting winches are presented in Tab.3. They relate to operation of the entire set hence they represent the total load of all hoisting winches in operation. Fig. 2 presents the histograms of operational loads of sets of manoeuvre hoisting winches on two selected dredgers. Like in the case of bucket chains the loads in question were grouped in 10 quantification intervals covering the range $\left(\mathrm{N}_{\mathrm{WM}}^{\min }-\mathrm{N}_{\mathrm{wM}}^{\max }\right)$.

In Tab. 3 are given the values of distribution parameters of loads of the sets of manoeuvre hoisting winches regardless of kind of soil. The earlier made investigations [6] did not confirm any significant influence of kind of soil on loads of set of manoeuvre hoisting winches.

The performed calculations of the load distribution parameters of the sets of manoeuvre hoisting winches showed that for particular dredgers the mean loads were contained within the interval of $0.072 \div 0.158$ with the mean value of
0.117 and the variation coefficient values in the interval of $0.254 \div 0.43$ with the mean value of 0.372 . For greater dredgers a noticeable increase of the mean relative load value can be observed. The fact results from greater values of relative effectiveness (i.e. the ratio of the operational effectiveness and design effectiveness) of greater dredgers as a result of their participation in investment operations. The influence of dredger effectiveness on demanded power of manoeuvre hoisting winches is known and described in many publications, e.g. $[11,12]$; this author described his own investigations on the theme in [6]. Values of the coefficients $\lambda_{\mathrm{WM}}^{\mathrm{cz}}$ are contained in the interval of $0.94 \div 0.99$ and they are practically identical to those of the coefficent $\lambda_{\mathrm{LC}}^{\mathrm{cz}}$.
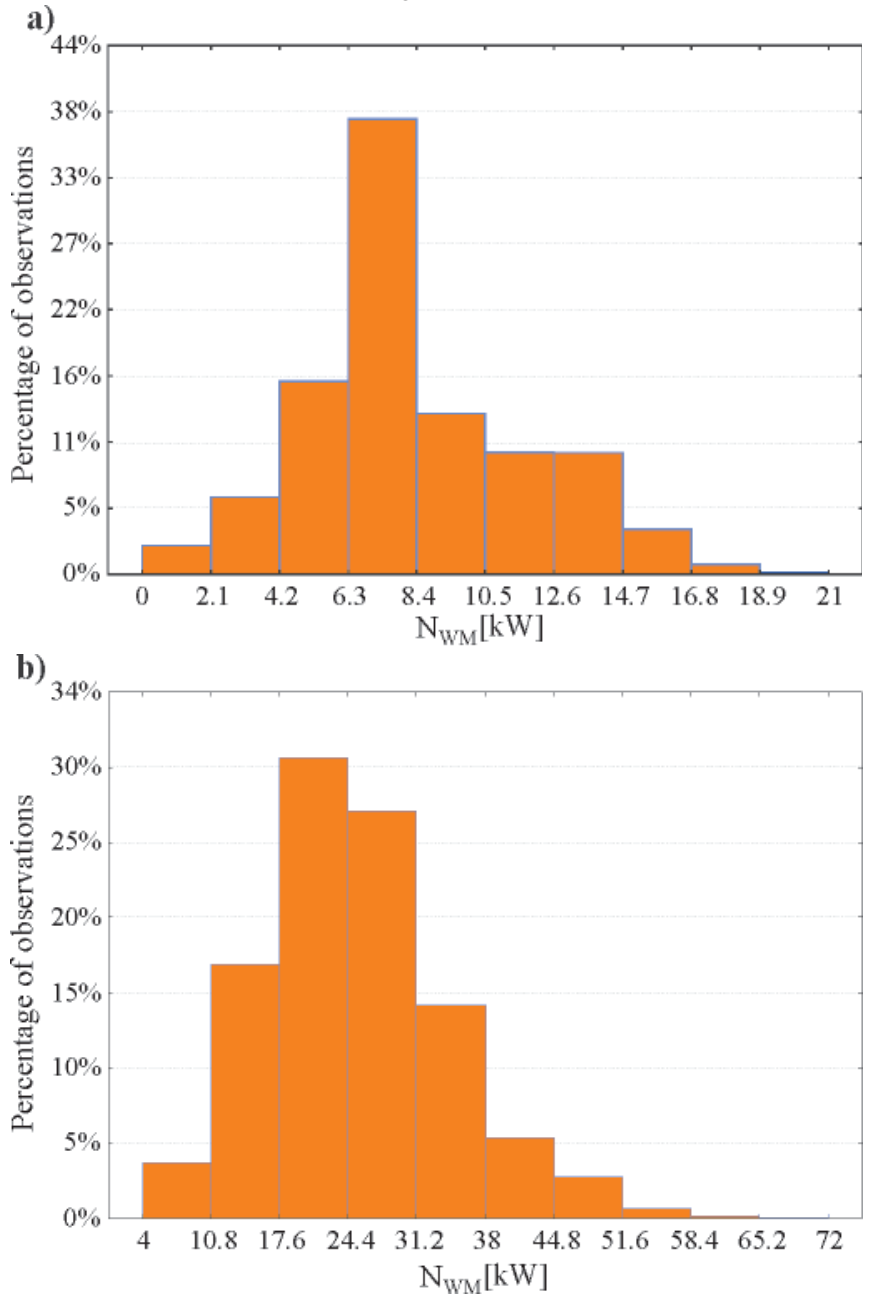

Fig. 2. Histograms of operational loads of sets of manoeuvre hoisting winches on the multi-bucket dredgers: a) Inż. T. Wenda, b) Kategats

Tab. 3. Characteristics of load distributions of sets of manoeuvre hoisting winches on multi-bucket dredgers

\begin{tabular}{|c|c|c|c|c|c|c|c|}
\hline \multirow{2}{*}{ Name of dredger } & $\sum^{*} \mathrm{~N}_{\mathrm{WM}}^{\mathrm{nom}}$ & $\mathrm{N}_{\mathrm{WM}}^{\mathrm{sr}}$ & $\overline{\mathrm{N}_{\mathrm{WM}}^{\mathrm{sr}}}$ & $\sigma_{\mathrm{WM}}$ & $v_{\mathrm{WM}}$ & $\lambda_{\mathrm{WM}}^{\mathrm{cz}}$ & \multirow{2}{*}{ Source of information } \\
\cline { 2 - 7 } & $\mathrm{kW}$ & $\mathrm{kW}$ & - & $\mathrm{kW}$ & - & - & \\
\hline Matż II & 44 & 3.16 & 0.072 & 1.36 & 0.43 & 0.96 & the author's investigations \\
\hline Inż. T. Wenda & 86 & 8.33 & 0.097 & 3.48 & 0.418 & 0.98 & ditto \\
\hline Rozgwiazda & 86 & 7.21 & 0.084 & 1.83 & 0.254 & 0.97 & ditto \\
\hline Usedom & 168 & 23.18 & 0.138 & 8.91 & 0.384 & 0.99 & ditto \\
\hline Kategats & 168 & 25.37 & 0.151 & 9.23 & 0.364 & 0.99 & ditto \\
\hline Ivan Bachalov & 168 & 26.47 & 0.158 & 10.04 & 0.379 & & {$[10]$} \\
\hline Man values & & & 0.117 & & 0.372 & 0.98 & \\
\hline
\end{tabular}


The coefficients $\lambda_{\mathrm{LC}}^{\mathrm{cz}}$ and $\lambda_{\mathrm{wM}}^{\mathrm{cz}}$ given in Tab. 2 and 3 determine duration of working time of bucket chain and set of manoeuvre hoisting winches during dredging the soil onto hopper barge (or silting-up the soil directly to land), respectively. To obtain time relation of the operational state "dredging" it is necessary to use additionally the coefficient $\lambda_{\mathrm{cz}}^{\mathrm{rp}}$ (participation of time of dredging only in overall time of dredging operations). For this coefficient the value equal to 0.9 can be approximately assumed [5].

\section{INVESTIGATIONS OF THE RELATIONS BETWEEN MEAN DRIVING LOADS OF MAIN CONSUMERS AND THEIR NOMINAL EFFECTIVE OUTPUT POWER VALUES}

The investigations of the relations between the mean operational driving loads of main consumers, $\mathrm{N}_{\mathrm{GO}}^{\mathrm{sr}}$, and their nominal effective output power values $\left(\mathrm{N}_{\mathrm{GO}}^{\mathrm{sr}}\right)^{\text {nom }}$ is very important for later possible use of their results in preliminary design stages of ship power plant.

As to the main consumers, the effective flux of energy of consumers, being in each case the product of the so called „generalized potential" and the ,generalized flow rate", can be considered [1].

The investigations of the relations between the mean driving loads of main consumers and their nominal effective output power values were already performed for industrial trawlers and typical transport ships (dry cargo ships, bulk carriers) $[1,3]$.

The performed investigations showed that for all types of main power consumers installed on the considered ships the following linear relation is valid $[1,3]$ :

$$
\mathrm{N}_{\mathrm{GO}}^{\mathrm{sr}}=\mathrm{a}+\mathrm{b}\left(\mathrm{N}_{\mathrm{GO}}^{\mathrm{uz}}\right)^{\mathrm{nom}}
$$

where:

$\mathrm{a}, \mathrm{b}-\mathrm{constants}$
The statement that the relation (1) appear to be linear and the possible determination of the constants $a, b$ is of great importance as it can be used to estimate output power of main engines of ships of the considered types during the offer or preliminary design phase $[1,3,5,9]$.

The effective bucket chain power is determined by the relation:

$$
\mathrm{N}_{\mathrm{LC}}^{\mathrm{uz}}=\mathrm{M}_{\mathrm{LC}} \cdot \omega_{\mathrm{LC}}
$$

where:

$\mathrm{M}_{\mathrm{LC}}$ - upper turas torque,

$\omega_{\mathrm{LC}} \quad-$ upper turas angular speed.

As bucket chain motion is forced by a prismatic rotary drum (called turas) cooperating with the bucket chain, located on a bucket tower, the bucket chain torque is assumed equal to the torque of the above mentioned upper turas. In the case of bucket chains, instead the angular speed, the bucket chain speed expressed by number of buckets passing the upper turas per one minute, as given in technical manuals of dredgers, is used.

In Tab. 4 are presented values of the nominal parameters of the bucket chains on the investigated dredgers as well as parameters of operational driving load distributions for the chains during dredging (on the basis of the data of Tab. 1 and 2). As stated earlier, there are no significant differences between mean values of bucket chain loads during dredging the medium sands and medium silts. Therefore the investigations of the relation (1) were carried out generally for medium soils, without distinguishing non-cohesive from cohesive ones. The investigations in question were performed for bucket chains by using the data of Tab. 4. Their results are presented in Tab. 5 and Fig. 3. The permissible intervals for independent variables of the equations given in Tab. 5 , result from the data contained in Tab. 4.

\begin{tabular}{|c|c|c|c|c|c|c|c|c|c|}
\hline \multirow{4}{*}{$\begin{array}{l}\text { Name of } \\
\text { dredger }\end{array}$} & \multicolumn{3}{|c|}{$\begin{array}{c}\text { Nominal parameters of bucket } \\
\text { chains }\end{array}$} & \multicolumn{6}{|c|}{ Characteristics of operational loads } \\
\hline & \multirow{2}{*}{$\mathrm{M}_{\mathrm{LC}}$} & \multirow{2}{*}{$\mathrm{n}_{\mathrm{LC}}$} & \multirow{2}{*}{$\mathrm{N}_{\mathrm{LC}}^{\mathrm{uz}}$} & \multicolumn{3}{|c|}{ Medium soils } & \multicolumn{3}{|c|}{ Light soils } \\
\hline & & & & $\mathrm{N}_{\mathrm{LC}}^{\mathrm{sr}}$ & $\sigma_{\mathrm{LC}}$ & $v_{\mathrm{LC}}$ & $\mathrm{N}_{\mathrm{LC}}^{\mathrm{sr}}$ & $\sigma_{\mathrm{LC}}$ & $v_{\mathrm{LC}}$ \\
\hline & $\mathrm{kNm}$ & $\begin{array}{l}\text { n.bckts/ } \\
\text { min }\end{array}$ & $\begin{array}{c}\mathrm{kNm} \cdot \\
\text { n.bckts/ } \\
\text { min }\end{array}$ & $\mathrm{kW}$ & $\mathrm{kW}$ & - & $\mathrm{kW}$ & $\mathrm{kW}$ & - \\
\hline Matż II & 85 & 24 & 2040 & 28.37 & 9.92 & 0.349 & 21.22 & 4.03 & 0.189 \\
\hline Inż. T. Wenda & 370 & 19 & 7030 & 104.09 & 37.06 & 0.353 & 92.73 & 14.28 & 0.154 \\
\hline Rozgwiazda & 360 & 19 & 6840 & 96.77 & 32.92 & 0.34 & 90.98 & 16.91 & 0.186 \\
\hline Usedom & 400 & 25 & 10000 & 183.44 & 41.62 & 0.227 & 158.93 & 29.93 & 0.188 \\
\hline Kategats & 380 & 25 & 9500 & 195.68 & 42.35 & 0.216 & 172.86 & 21.48 & 0.124 \\
\hline Ivan Bachalov & 380 & 25 & 9500 & 186.64 & 46.84 & 0.251 & 165.91 & 28.67 & 0.173 \\
\hline
\end{tabular}

Tab. 4. Nominal parameters of bucket chains and characteristics of their operational loads during dredging for 6 investigated dredgers

Tab. 5. Linear regression equations which describe mean loads of bucket chains during dredging the soil of two kinds

\begin{tabular}{|c|c|c|c|c|c|c|}
\hline \multirow{2}{*}{ Kind of soil } & \multicolumn{2}{|c|}{ Form of relation } & \multicolumn{5}{|c|}{ Statistical estimation parameters } \\
\cline { 3 - 7 } & & $\mathrm{R}$ & $\sigma[\mathrm{kW}]$ & $\mathrm{F}$ & $\mathrm{F}_{\mathrm{kr}} ; \alpha=0.05$ & $\mathrm{~m}$ \\
\hline medium & $\left(\mathrm{N}_{\mathrm{LC}}^{\mathrm{sr}}\right)=0.0216\left(\mathrm{~N}_{\mathrm{LC}}^{\mathrm{uz}}\right)-29.44$ & 0.965 & 23.16 & 55.35 & 7.71 & 6 \\
\hline light & $\left(\mathrm{N}_{\mathrm{LC}}^{\mathrm{sr}}\right)=0.0194\left(\mathrm{~N}_{\mathrm{LC}}^{\mathrm{uz}}\right)-27.84$ & 0.973 & 18.28 & 71.15 & 7.71 & 6 \\
\hline
\end{tabular}

where: $\mathrm{R}$ - coefficient of correlation, $\sigma-$ standard deviation 


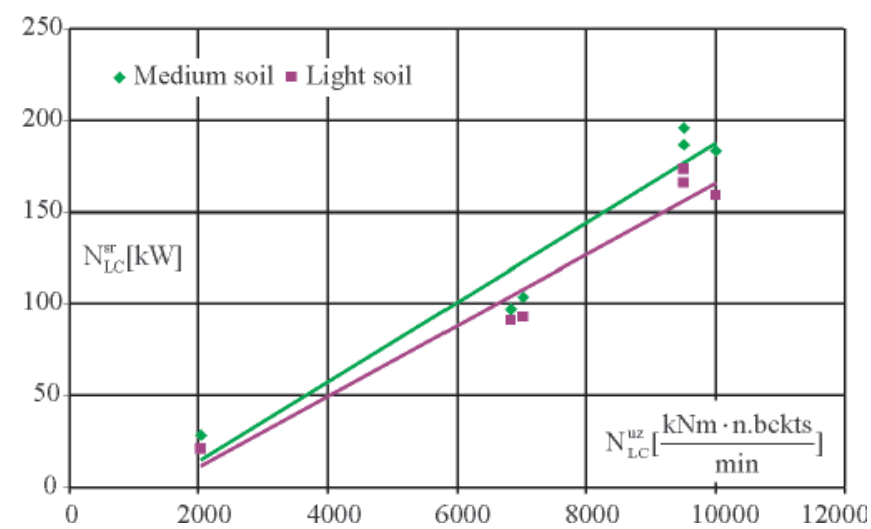

Fig. 3. The relation: $N_{L C}^{s r}=f\left(N_{L C}^{u z}\right)$ for multi-bucket dredgers

To investigate significance level of correlation coefficient the F test of Snedecor distribution was used. Statistical significance is confirmed if: $\mathrm{F}>\mathrm{F}_{\mathrm{kr}}$ for the assumed significance level $\alpha$ (usually $\alpha=0.05$ ) and the degrees of freedom: $\mathrm{s}_{1}$ and $\mathrm{s}_{2}$ $\left(\mathrm{s}_{1}=1, \mathrm{~s}_{2}=\mathrm{m}-1-1\right.$, where: 1 - number of independent variables, $\mathrm{m}$ - number of population).

The nominal effective output power of set of manoeuvre hoisting winches, $\mathrm{N}_{\mathrm{WM}}^{\mathrm{uz}}$, is described by the relation:

$$
\mathrm{N}_{\mathrm{WM}}^{\mathrm{uz}}=\sum_{\mathrm{i}=1}^{4}\left(\mathrm{~T}_{\mathrm{WM}} \cdot \mathrm{v}_{\mathrm{WM}}\right)_{\mathrm{i}}
$$

where:

$\begin{array}{ll}\mathrm{T}_{\mathrm{WM}} & - \text { hoisting winch torque, } \\ \mathrm{v}_{\mathrm{WM}} & - \text { hoisting winch speed. }\end{array}$

In Tab. 6 are given the nominal parameters of manoeuvre hoisting winches on the investigated dredgers as well as parameters of operational load distributions of sets of the winches during dredging (on the basis of the data given in Tab. 1 and 3). The investigations of the relation (1) were performed jointly for the whole duration time of the state „dredging” regardless of kind of soil dredged by a given dredger.

By making use of the data of Tab. 6 the following relation was obtained (Fig. 4):

$$
\mathrm{N}_{\mathrm{WM}}^{\mathrm{sr}}=0.2343\left(\mathrm{~N}_{\mathrm{WM}}^{\mathrm{uz}}\right)-7.65
$$

for which the values of: the correlation coefficient $\mathrm{R}=0.986$, the standard deviation $\alpha=2.06 \mathrm{~kW}$, the test $\mathrm{F}=148.64$ at the population number $\mathrm{m}=6$, and $\mathrm{F}_{\mathrm{kr}}=7.71$ for $\alpha=0.05$, were calculated. The relation is applicable within the range: $38 \leq \mathrm{N}_{\mathrm{WM}}^{\mathrm{uz}} \leq 138 \mathrm{~kW}$.

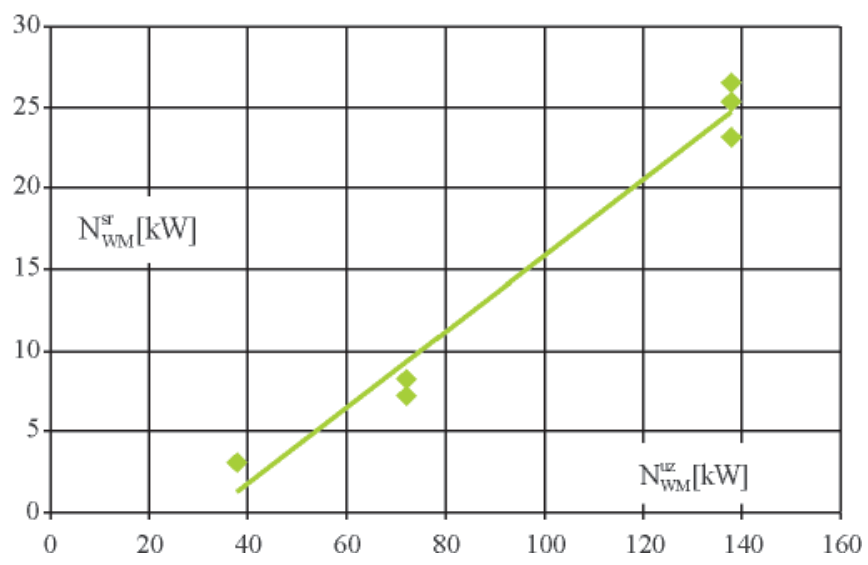

Fig. 4. The relation: $N_{W M}^{s r}=f\left(N_{W M}^{u z}\right)$ for multi-bucket dredgers

\section{SUMMARY}

The performed investigations of operational loads of bucket chains and sets of manoeuvre hoisting winches on multi-bucket dredgers make it possible to offer the following remarks and conclusions:

$O$ the averaged load distribution parameters of bucket chains and sets of manoeuvre hoisting winches, given in Tab. 2 and 3, can be deemed typical for the entire population of multi-bucket dredgers because of the long-lasting period of measurements as well as the broad range of size of the tested dredgers

the characteristics of operational bucket chain loads, given in Tab. 2, confirm the necessity of taking into account kind of dredged soil

$O$ in both the cases, i.e. of bucket chains and set of manoeuvre hoisting winches, the linearity of the relation (1) was confirmed as in all the considered relations large values (over 0.95 ) of the correlation coefficient $\mathrm{R}$ were obtained

$O$ the achieved results can be used for predicting load distributions of bucket chains and manoeuvre hoisting winches; the relations given in Tab. 5 can be used to determine mean load of bucket chains; the relation (4) can be used to determine mean load of set of manoeuvre hoisting winches; the values of variation coefficients of load distributions of bucket chains and set of manoeuvre hoisting winches given in Tab. 2 and 3, can be used to estimate standard deviations of operational loads of the above mentioned main power consumers

$O$ the presented results can be useful in solving problems during preliminary design phases of power plants for multibucket dredgers.

\begin{tabular}{|c|c|c|c|c|}
\hline \multirow{3}{*}{ Name of dredger } & \multirow{2}{*}{$\begin{array}{c}\begin{array}{c}\text { Nominal effective } \\
\text { power }\end{array} \\
\mathrm{N}_{\mathrm{WM}}^{\mathrm{uz}}\end{array}$} & \multicolumn{3}{|c|}{$\begin{array}{l}\text { Characteristics of operational loads of set } \\
\text { of manoeuvre hoisting winches }\end{array}$} \\
\hline & & $\mathrm{N}_{\mathrm{wM}}^{\mathrm{sr}}$ & $\sigma_{\mathrm{wM}}$ & $v_{\mathrm{wM}}$ \\
\hline & $\mathrm{kW}$ & $\mathrm{kW}$ & $\mathrm{kW}$ & - \\
\hline Malż II & 38 & 3.16 & 1.36 & 0.43 \\
\hline Inż. T. Wenda & 72 & 8.33 & 3.48 & 0.418 \\
\hline Rozgwiazda & 72 & 7.21 & 1.83 & 0.254 \\
\hline Usedom & 138 & 23.18 & 8.91 & 0.384 \\
\hline Kategats & 138 & 25.37 & 9.23 & 0.364 \\
\hline Ivan Bachalov & 138 & 26.47 & 10.04 & 0.379 \\
\hline
\end{tabular}

Tab. 6. Nominal effective power of set of manoeuvre hoisting winches and their operational load characteristics during dredging for 6 investigated dredgers 


\section{BIBLIOGRAPHY}

1. Balcerski A.: Probabilistic models in the theory of design and operation of ship power plants (in Polish). Fundacja Promocji Przemysłu Okrętowego i Gospodarki Morskiej (Foundation for promotion of shipbuilding industry and maritime economy), Gdańsk 2007

2. Balcerski A., Bocheński D.: Proposal of a new structure of notions associated with ship power system (in Polish). Materiały XXIII Sympozjum Siłowni Okrętowych SymSO 2002 (Proceedings of 23rd Symposium on ship power plants SymSO 2002), Gdynia 2002

3. Balcerski A., Bocheński D.: Investigations of relations of mean driving loads of technological consumers on industrial floating units (in Polish). Zeszyty Naukowe Wyższej Szkoły Morskiej w Szczecinie (Scientific Bulletins of Szczecin Maritime University), Szczecin 2003

4. Bocheński D., Kubiak A., Jurczyk L.: Measurements of the parameters which characterize operation of technological systems on dredgers (in Polish). Materiały XXII Sympozjum Siłowni Okrętowych SymSO 2001(Proceedings of 22nd Symposium on ship power plants SymSO 2001), Szczecin 2001

5. Bocheński D. (Superviser) et al.: Research on identification energy consumption and parameters of dredging as well as winning transport on selected types of dredgers and pumping dredgers. Final report of the research project $K B N$ no. $9 T 12 C 01718$ (in Polish). Prace badawcze WOiO PG nr 8/2002/PB (Research report No.8/2002/PB, Faculty of Ocean Enginering and Ship Technology, Gdańsk University of Technology), Gdańsk 2002

6. Bocheński D.: Analysis of operational loads of main power consumers on multi-bucket dredgers (in Polish). Zeszyty Naukowe Akademii Marynarki Wojennej nr 162. XXVI (Scientific Bulletins of Polish Naval University, No. 162, XXVI), Sympozjum Siłowni Okrętowych SymSO 2005 (Proceedings of 26th Symposium on ship power plants SymSO 2005), Gdynia 2005

7. Bocheński D.: Analysis of design solutions and relations which determine parameters of power systems of multi-bucket dredgers (in Polish). Wybrane problemy projektowania i eksploatacji siłowni okrętowych (Selected problems of design and operation of ship power plants), XXVII Sympozjum Siłowni Okrętowych SymSO 2006, (Proceedings of 27th Symposium on ship power plants SymSO 2006), Szczecin 2006

8. Bocheński D.: Operational loads of power system of bucket dredgers in main service states. Journal of Polish CIMAC, Energetic aspects vol. 2, no 1, Gdańsk 2007

9. Bobrowski D.: Probabilistics in engineering applications (in Polish). WNT (Scientific Technical Publishing House), Warszawa 1986

10.Kompleksyjne technologiczieskie issledowanija sudov popolnienija instrukcyja po effjektiwnoj eksploatacji ziemsnarjada „Ivan Bachalov” (in Russian). GDK, Rostow upon Don, 1985

11.Roorda A., Vertregt J.J.: Floating dredgers. De Technische Uitgeverij H.Stam, Haarlem, 1963

12.Vlasblom W. J.: Designing dredging equipment. Lecture notes, TUDelft 2003-05

13.Girtler J.: Deterministic and probabilistic interpretation of operation of technical systems with regard to their reliability. Polish Maritime Research, No 3/2003

14.Bocheński D.: Design solutions and working conditions of power systems for trailing suction hopper dredgers. Polish Maritime Research, No 2/1999

15. Girler J.: A probabilistic concept of load assessment of selfignition engines, Polish Maritime Research, No 2/2008

\section{CONTACT WITH THE AUTHOR}

Damian Bocheński, Ph. D.

Faculty of Ocean Engineering and Ship Technology

Gdansk University of Technology

Narutowicza 11/12

80-952 Gdansk, POLAND

e-mail : daboche@pg.gda.pl

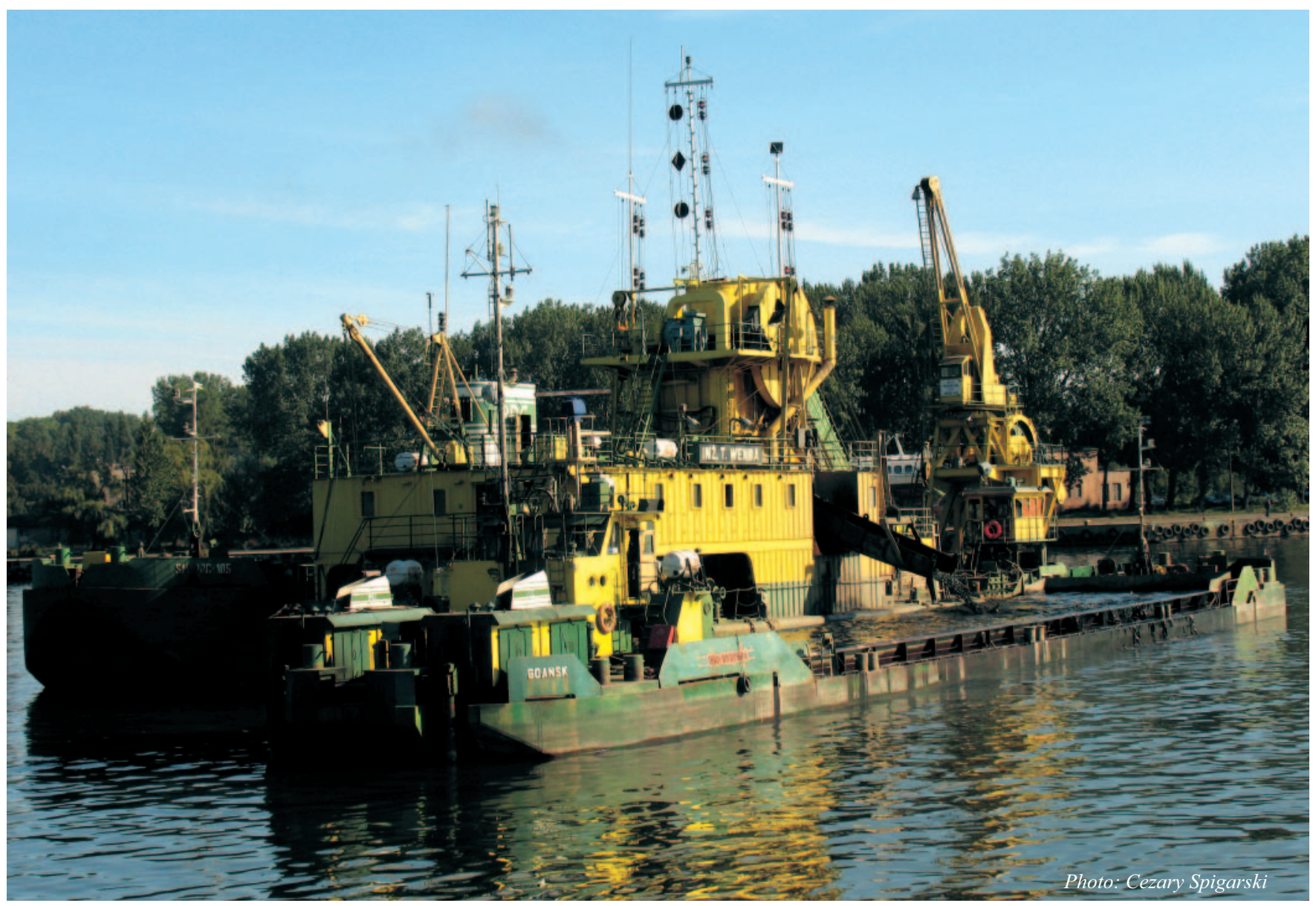

